\title{
Imperialism as the Truth about Capitalism
}

In Kautsky's analysis of imperialism, the economic relations of capitalism are transformed into pure relations of power. Monopolistic profits are made possible either by artificially high prices of commodities or interests on investments exported to foreign colonies or dependent countries. The state is a political instrument in the hands of finance capital, and its economic policy favours cartels and trusts, and finance capital. In Kautsky's reasoning, imperialism is, furthermore, a pure question of power. The accentuated role of power in Kautsky's thinking about imperialism resulted from the seemingly paradoxical thesis that imperialism is a product of the economic development of capitalism and yet it is not an economic necessity in developed capitalism (in fact, imperialism is disadvantageous even from the point of view of capital accumulation). Once imperialism is understood to be a result of a relation of power, the thesis becomes theoretically non-contradictory. There are different methods for coping with the problems facing the accumulation of capital, of which imperialism is only one possible alternative, and the choice between different methods is made by the factual power constellation in society.

Kautsky's analysis of imperialism has been shown to be two-sided: On the one hand, imperialism is found to be determined by the natural qualities of the different sectors of production. The relations between industrial and agrarian countries are determined by the natural obstacles of the development of agrarian production; industrial overproduction is a result of natural - and not of any specific social - limits of agrarian production. As such, the contradiction causing imperialism would not seem to be resolvable at all. There are only different methods for coping with it, of which imperialism is only one possible (although historically prevalent) method. And the different methods of coping with overproduction are shown to be dependent on the power relations in society. On the other hand, in Kautsky's analysis, imperialism is a result of the centralisation of capital, of the formation of trusts and cartels, and of finance capital, which increase the problems of overproduction of commodities and capital, and are able to regulate production. Being especially powerful groups of capital, big, centralised capitalists also force the capitalist state to apply imperialistic methods in its politics.

In analysing Kautsky's conception of the law of capitalist appropriation, it was argued that he understood the capital-wage labour relation essentially as a relation of direct exploitation. To him, freedom and equality were essentially 
characteristics of an earlier mode of production, simple commodity production, in which the appropriation of commodities and private property were consequently based on the labour of every producer, whereas in capitalism the right to property is based on the appropriation of alien labour and its products. Consequently, Kautsky comprehended the capital relation not as a specific socially mediated relation of exploitation recognising the (formal) freedom and equality of commodity producers, but as a relation of unequal exchange based on direct dominance and power.

It could thus be claimed that Kautsky's theory of imperialism was a logical result of his concept of capital; as a matter of fact, it is in imperialism that the true nature of capitalism is revealed and becomes visible to everyone. In imperialism, the relations of production are in fact replaced by relations of power and dominance. Finance capital is understood to exploit not only wage workers, but all consumers and even other producers by artificially increasing the prices of products and lowering the prices of raw materials. This new method of appropriation of profits is based on political power exercised through the state by finance capital; it is furthermore based on direct repression and violence both at home and abroad. Imperialism reveals the exploitative nature of capitalism at its clearest. Instead of from the capital-labour relation, monopolistic profits predominantly result from the unequal exchange of commodities or from the distribution of the whole national product in the interests of cartels and finance capital. As a result, there cannot be any talk of even the illusions of freedom and equality between the exploiters and the exploited.

As already pointed out, there are important similarities and differences between Lenin's concept of imperialism and that of Kautsky. Lenin did not emphasise the relation between agrarian and industrial countries in his analysis, even though he referred to it as one of the reasons for overproduction. While emphasising monopoly as the economic essence of imperialism, he understood imperialism mainly as a result of the centralisation of capital and the formation of finance capital transforming the functioning of the laws of competition in capitalism. There are not, therefore, any natural or technical conditions for production influencing the rise of imperialism - unless one understands the increasing amount of capital necessary for production to be such a condition. There is an interesting ambivalence in Lenin's thinking which becomes explicit in his critique of Bucharin: On the one hand, imperialism does not transform the functioning of capitalist laws from bottom to top and consequently does not represent a totally different mode of production. There is more concrete evidence of this in Lenin's analysis of the monopolistic competition taking place side by side with free competition; free competition is not totally abolished by monopolies. The denial of the possibility of the develop- 
ment of capitalism into a general cartel or into ultra-imperialism is a further indicator of this fact. On the other hand, these reservations did not seem to have much influence on Lenin's general analysis of the functioning and consequences of imperialism. Even Lenin constantly referred to the economic power and dominance of monopolies as the source of their extra-profits. Monopolies maintain artificially high prices and exploit the whole nation. Their foreign investments bring them a highly profitable interest and through them other nations are exploited too. Monopolies further lead to the stagnation of the productive forces. They also represent repression and violence in their own country and in international relations, and are undemocratic by their very nature. Even to Lenin, then, imperialism became practically synonymous with an economic system violating the rules of commodity exchange, the equality and freedom of the commodity owners; imperialism is essentially based on a forced distribution of the surplus product of the whole hemisphere determined by the power of the big capital magnates.

Moishe Postone and Barbara Brick, in a totally different context discussing Pollock's theory of 'state capitalism', highlighted a general characteristic of what they understood to be the essence of traditional Marxism. In the conceptions of traditional Marxism, the relations of production are basically identified with the relations of distribution: 'The ultimate concern of this theory, then, is the historical critique of the mode of distribution'. ${ }^{1}$

Socialism is simply understood to be a mode of distribution more appropriate to the industrial mode of production - the centralisation and concentration of production has given rise to new possibilities for centralised planning and for overcoming private property. This interpretation of Marxism further takes in an understanding of industrial production essentially as a technical process, a labour process that is not intrinsically socially determined. ${ }^{2}$

Postone's and Brick's characterisation of traditional Marxism seems to be especially fitting to the theories of imperialism of the Second International. Capitalism is fundamentally analysed as a process of distribution - monopolistic profits basically have their source in the sphere of circulation, and not in production. Hilferding states this explicitly: the remaining antagonism of the new capitalism is an antagonism of distribution. The characterisation of traditonal Marxism as understanding the production process as a technical labour process is also an adequate one; one could even claim that the technical prerequisites for the production process play an even more important role in these

1 Postone and Brick 1982, p. 631; see also Linder 1973, p. 74.

2 Postone and Brick 1982, pp. 630-1. 
theories as the technical or even natural properties of production are understood to be the main cause of monopolisation and imperialism. This is most clearly the case in Kautsky's and Hilferding's theories of modern capitalism, but even to Lenin the new technical conditions of production were among the reasons behind the formation or coming into being of trusts and cartels. ${ }^{3}$

The conception of capitalism inherent in the theories of imperialism has serious consequences for the strategic conclusions drawn from it and especially for the understanding of the role of democracy in capitalism. The most obvious consequence is connected with the analysis of the formation of revolutionary consciousness and a revolutionary subject. Once again, Kautsky presented the problem in a most consistent manner. Since his theory excluded a categorical mediation between the exploitation of surplus value and the exchange of commodities as equivalents on the market, he was forced to adopt a dual conception of consciousness. On the one hand, the exploitative nature should be obvious to the proletariat - and, in imperialism, to the rest of the population as well - and the economic development of capitalism is expected to lead automatically to the formation of a revolutionary subject, a revolutionary working class. On the other hand, the economic interests of the wage workers are not immediately identical with the wider socialist perspective. There is thus a major difference between the economic, or - to use Lenin's expression - trade-unionistic consciousness and the socialist consciousness of the proletariat. The socialist intellectuals, representing scientific socialism, and the socialist party are a necessary link connecting socialism with the labour movement. The Social Democratic Party is the representative of scientific socialism possessing the right knowledge about the socialist goal of social development. As will be seen in more detail later on, Lenin followed Kautsky's formation of the problem in practically all of its essential elements.

One would expect the analysis of imperialism to have led Kautsky and Lenin to problematise their conceptions about the formation of revolutionary consciousness and of a revolutionary subject - if not otherwise, then at least as a problem of the relation between the theory and programme of the party and the political reality of modern capitalism. As a theoretical question, however, the problem no longer existed for them. When analysis of the capital relation was substituted by analysis of exploitation by finance capital mediated through the state, the antagonism between workers and capitalists was substituted by the antagonism between the rest of the people and a finance oligarchy. As a consequence, exploitation should become obvious and visible to everyone, as

3 Cf. Linder 1973, p. 74. 
proved most obviously by the case of a general cartel - which, in a sense, is a logical conclusion of Kautsky's and Lenin's reasoning: capitalism, in the form of a general cartel or a handful of big capitalists, could not possibly survive, because its exploitative nature would be developed to absurdity. Hence, it really is surprising how anyone could expect imperialism to survive while it is only in the interest of a negligible fraction of the population, namely, the tiny fraction of finance capitalists. The realisation of socialism should self-evidently be in the interests of all the people.

As in the case of his earlier analysis, Kautsky referred to auxiliary explanations in order to save his conception of the people as the potential opponent of imperialism. From the point of view of their economic interests, it is relatively easy to show that the various middle-class groups - intellectuals, farmers, the old petit bourgeoisie - have no direct economic interests in supporting imperialism. The case of the proletariat should be even more obvious. Its interests are clearly and directly opposed to those of finance capital. However, Kautsky claimed that the situation is complicated because the supporters of imperialism have a strong instrument of power at their disposal and therefore are able to influence large segments of the population both economically and ideologically. ${ }^{4}$ In Lenin's work on imperialism, the rise of a labour aristocracy similarly explained the reformist tendencies in the labour movement; certain groups of workers have been bought out by the imperialists. (In Lenin's earlier thinking, the problem was tackled with the dual theory of consciousness.)

A second important problem of the theories of imperialism and the conception of capitalism in general is the question of democracy, both in its role within the strategy of the Social Democratic Party and in its relation to capitalism and socialism. In this respect, it becomes even more obvious that imperialism reveals the truth about capitalism. Since imperialism is essentially determined by the relations of power and dominance, democracy and imperialism are mutually exclusive. Imperialism does not just prove that the bourgeoisie has betrayed its former ideals of democracy and freedom, but imperialism is undemocratic by its very nature. A form of exploitation mediated more or less directly by the capitalist state could not possibly persist within a democratic state. The realisation of a parliamentary democracy and the guarantee of the political rights of all the people would automatically result in the establishment of the power of the proletariat. The fight for democracy thus factually becomes identical with the fight for socialism.

4 Kautsky 2011d, p. 810. 
In Kautsky's conception of political democracy and its role in the struggle for socialism, this standpoint is formulated most explicitly. But one could also claim that despite Lenin's vehement critique of Kautsky's conceptions of democracy and the dictatorship of the proletariat, his own analysis of democracy did not differ all that markedly from that of Kautsky. In Lenin's analysis, democracy is something totally external to bourgeois society. 